
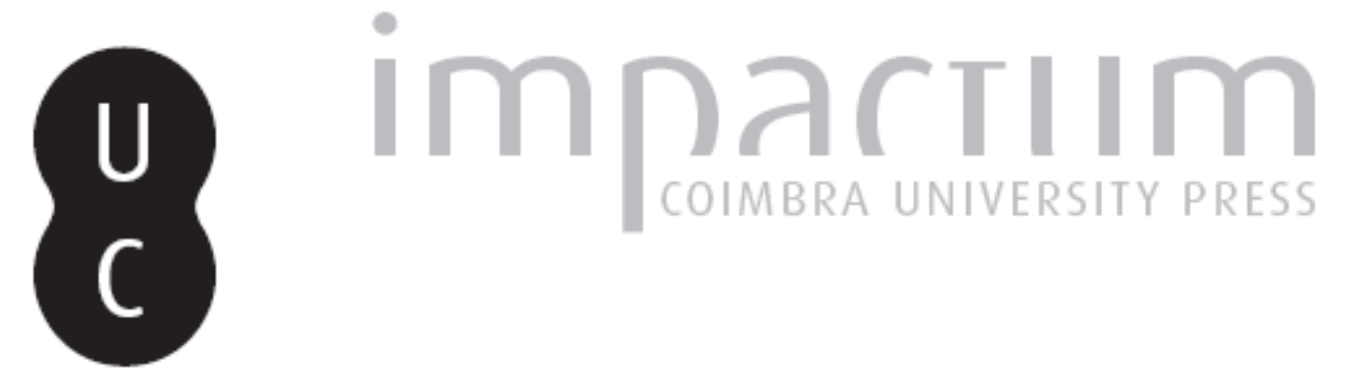

\title{
The role of financial constraints in the services sector: how different is it from manufacturing?
}

Autor(es): $\quad$ Silva, Filipe; Carreira, Carlos

Publicado por: Imprensa da Universidade de Coimbra

URL persistente:

URI:http://hdl.handle.net/10316.2/39054

DOI:

DOI:http://dx.doi.org/10.14195/2183-203X_43_2

Accessed : $\quad$ 26-Apr-2023 02:44:16

A navegação consulta e descarregamento dos títulos inseridos nas Bibliotecas Digitais UC Digitalis, UC Pombalina e UC Impactum, pressupõem a aceitação plena e sem reservas dos Termos e Condições de Uso destas Bibliotecas Digitais, disponíveis em https://digitalis.uc.pt/pt-pt/termos.

Conforme exposto nos referidos Termos e Condições de Uso, o descarregamento de títulos de acesso restrito requer uma licença válida de autorização devendo o utilizador aceder ao(s) documento(s) a partir de um endereço de IP da instituição detentora da supramencionada licença.

Ao utilizador é apenas permitido o descarregamento para uso pessoal, pelo que o emprego do(s) título(s) descarregado(s) para outro fim, designadamente comercial, carece de autorização do respetivo autor ou editor da obra.

Na medida em que todas as obras da UC Digitalis se encontram protegidas pelo Código do Direito de Autor e Direitos Conexos e demais legislação aplicável, toda a cópia, parcial ou total, deste documento, nos casos em que é legalmente admitida, deverá conter ou fazer-se acompanhar por este aviso.

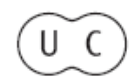




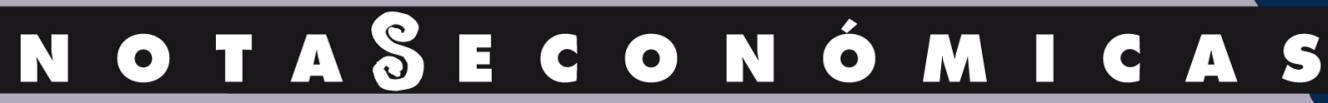

AUEUSTO SANTOS SILVA

FILIPE SIIVA / CARLOS CARREIRA
COMO PENSAR NA GLOBALIZAÇÃO? CONTRIBUTO SOCIOLOGGICO PARA UM MODELO DE ANÁLISE INTERDISCIPLINAR

THE ROLE OF FINANCIAL CONSTRAINTS IN THE SERVICES SECTQR: HOW DIFFERENT IS IT FROM MANUFACTURING?
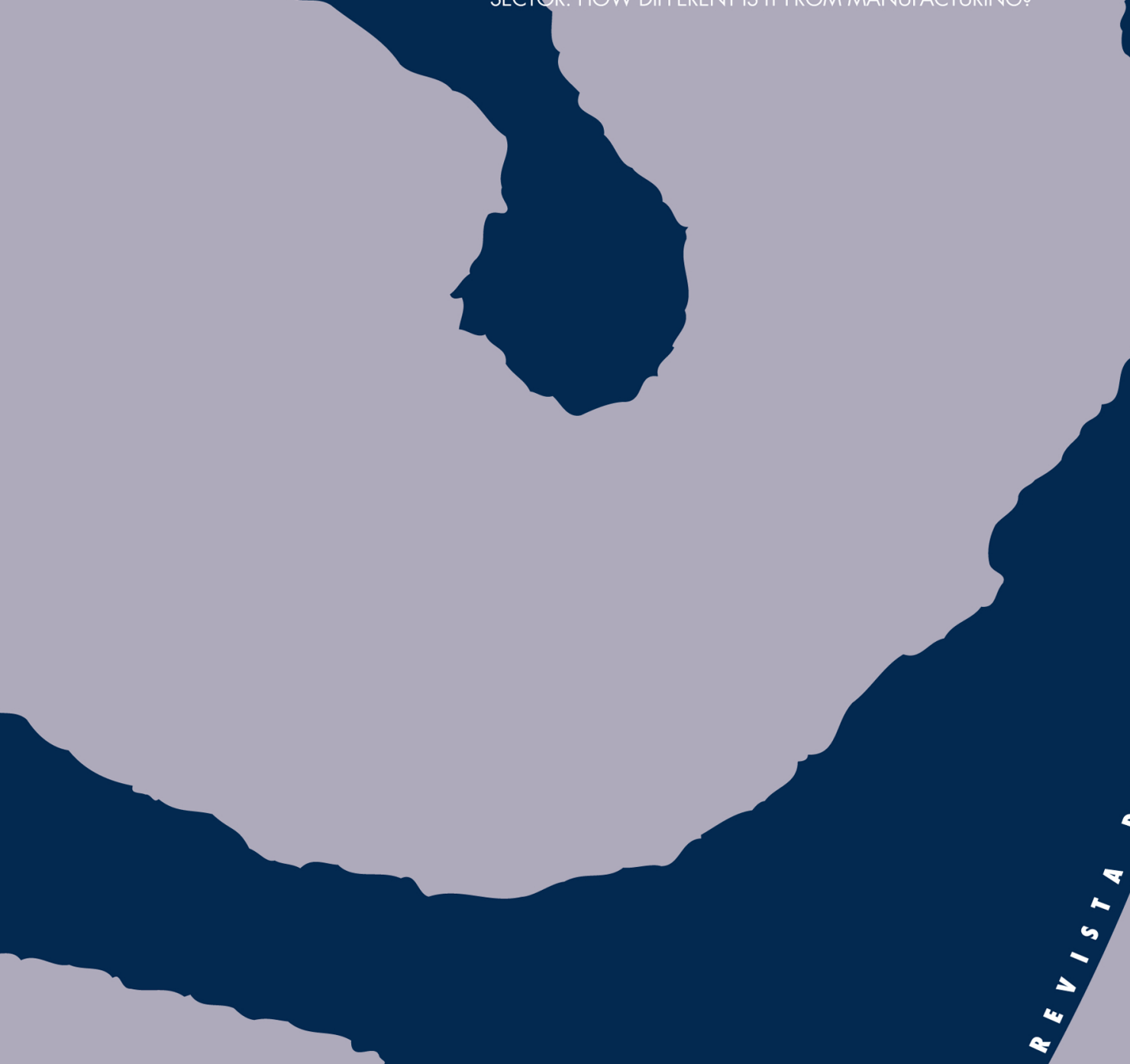

4

-

a

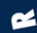

u

$\Rightarrow$

$-$

$z$

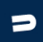

4

a

$a$

-

E

$\bullet$

2

○

$u$

w

4

$\theta$

4

$\theta$

8

0

$-$

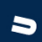

$u$

4

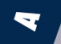




\section{The Role of Financial Constraints in the Services Sector: How Different is it from Manufacturing?}

Although the services sector has emerged as a major contributor to gross domestic product and employment in developed economies, very little attention has been paid to financial constraints faced by services firms. This paper represents a first attempt to model financial constraints in the services sector. In particular, we question the commonly accepted inverse relationship between firm size/age and financial constraints. To conduct our empirical tests, we estimate the CashCash Flow Sensitivity using a large unbalanced panel of Portuguese firms. We also combine the recently developed Hovakimian-Hovakimian index of firm's financial constraints with the sensitivity of cash stocks to cash-flow approach. Our results suggest that there are clear differences in financial constraints across the two sectors. First, firms operating in the services sector suffer from more severe financial constraints than those in manufacturing. Second, the relationship between size and financial constraints appears to be inverse in the case of the manufacturing sector, but not in services, for which we have U-shaped evidence. Finally, for the services sector we find some evidence suggesting an inverse relationship between age and financial constraints, while in manufacturing this relationship seems to be U-shaped.

Keywords: Services sector, financial constraints, cash-cash flow sensitivity, firm-level studies

JEL Classification: L8; D92; G32; L00; L2 
A new wave of empirical research aimed at the study of the services sector has emerged in the last decades, motivated by the growing size and importance of this sector in modern economies, on the one hand, and the new high-quality data that has become available to researchers, on the other. The increasing relevance of the services sector is the result of a long-term production reorganization due to both the increasing households' demand for services and the technological and organizational change within firms.

Despite the growing body of empirical literature that compares services and manufacturing, comparatively little is actually known about financial constraints faced by services firms. But understanding financial constraints in the services sector is certainly an important issue. Indeed, if financial constraints are more severe in the services sector, particularly in industries that are technology-intensive (Kukuk and Stadler, 2001), not only firm growth but also innovation and technological diffusion will be strongly affected and, consequently, economic growth.

It is not clear whether we should expect significant differences in financial constraints across sectors. On the one hand, services firms will require, on average, a lower initial physical capital investment than manufacturing firms, so that we would expect lower constraints for the former. On the other, for most services, the main input is human capital while the output is of an intangible nature, which are both harder to use as collateral when resorting to external finance.

The main purpose of this paper is to shed further light on financial constraints faced by services firms. Particularly, we test whether there are significant differences in financial constraints between manufacturing and services sectors. It is also in the scope of the paper to substantiate if previously devised relationships between financial constraints and firm size and age hold for economic sector disaggregation. Additionally, we combine the recently developed Hovakimian-Hovakimian index of constraints with the sensitivity of cash stocks to cash-flow framework, which is also novel in the literature.

The remainder of this paper proceeds as follows. Section 2 illustrates the underlying theoretical investment model and formulates the main hypotheses to be tested. Section 3 discusses the dataset and the main variables. It also outlines our empirical methodology. Section 4 presents the main results, while Section 5 pulls the pieces together and concludes the paper.

\section{Financing constraints in the services sector: What should we expect?}

The simple model of firm-level investment behaviour provides a useful framework to understand whether significant differences in the severity of financial constraints should be expected across sectors (Carpenter and Petersen, 2002a, 2002b). Following the 'percentage of sales approach', we assume for simplicity that the ratio of capital required in production to sales is constant, that is, $\theta=Y_{i t} / K_{i t}$, where $Y_{i t}$ and $K_{i t}$ are the sales and the capital stock of firm $i$ in period $t$, respectively (Higgins, 1977; Demirgüç-Kunt and Maksimovic, 1998). Thus, the required capital investment is proportional to the firm's increase in sales:

$l_{i t}=\theta^{-1} \Delta Y_{i t}$

The essential features of the model are illustrated in Figure 1. The horizontal axis measures either the investment expenditure or the increase in sales as well as the flow of finance, whereas the vertical axes measures both the marginal rate of return on expansion and the marginal cost of capital. The downward-sloping schedule represents the firm's demand for capital (i.e. the demand for investment funds), which is derived from the marginal returns to expanding its capital stock $(M R I)$, once all inputs have been optimally selected. ${ }^{1}$ The upward-sloping marginal cost of capital

1 The $M R I$ schedule can be expressed as $M R I=M R P \cdot M P K$, where MRP is the marginal revenue of the firm's demand schedule for its output and MPK is the marginal physical product schedule of capital stock. 
(MCC) schedule describes the supply of funds, reflecting the opportunity cost of alternative uses of funds. The horizontal section of the MCC schedule represents the cost of internal funds that are available at a constant cost until they are exhausted, at which point the firm must turn to external (debt and equity) finance, which may be substantially more costly because of adverse selection and moral hazard problem. ${ }^{2}$ Adverse selection problems arise when suppliers of external finance have incomplete information about the riskiness of firms' investment projects, leading to an increase in interest rates (which contains a lemons premium) that penalizes low risk projects. Problems of moral hazard arise as firms, whose actions cannot be monitored by suppliers of external finance, have an intrinsic incentive to invest in riskier, higher-return, projects once they have received the external funds. These two problems can be magnified if firms' assets have low collateral value.

\section{Figure 1. Firm investment behaviour in an imperfect capital market}

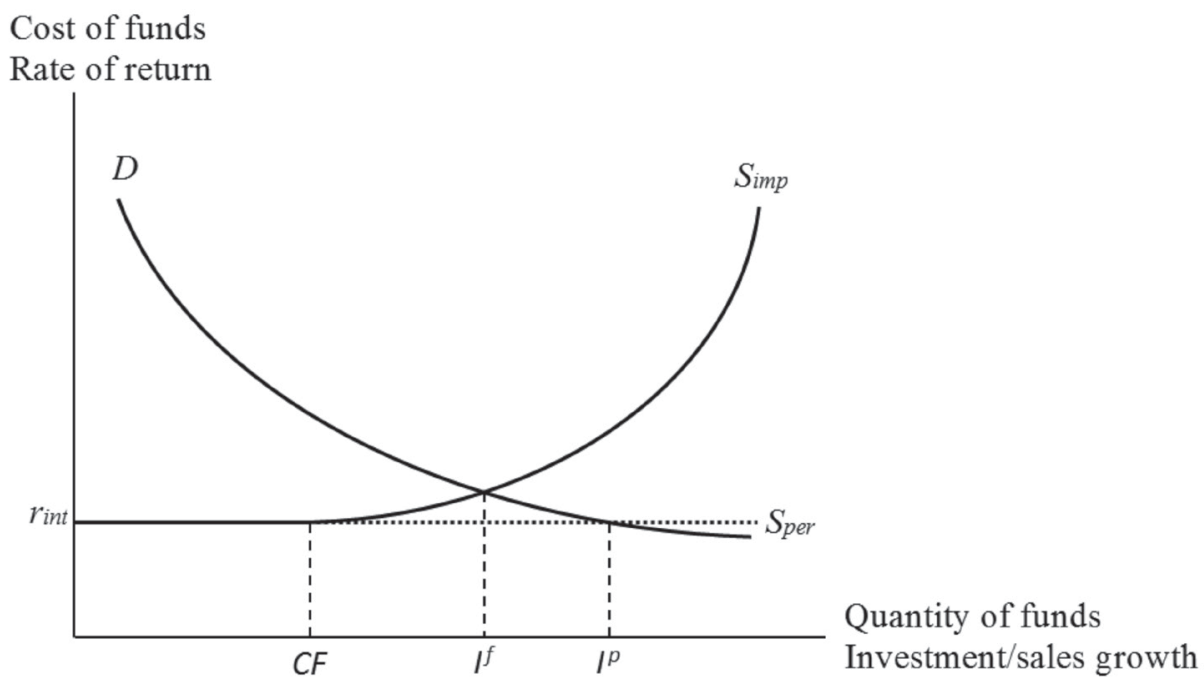

Notes: $D=$ demand for investment schedule; $S_{i m p / p e r}=$ supply of finance schedule in an imperfect/perfect capital market; $r_{\text {int }}=$ constant marginal cost of internal finance; $C F=$ internal finance (proxied by cash flow).

As Figure 1 shows, in equilibrium, the optimal level of investment for expansion is found at $I^{f}$, where the marginal return to investment and the marginal cost of capital are equalized. This level of investment is lower than the desired investment if the firm faces a perfect capital markets $\left(I^{f}<I^{P}\right)$. Indeed, beyond $C F$, the firm has to acquire external funds incurring in additional costs that tend to increase with the degree of leverage. The model thus predicts that firms that are dependent on external finance are more likely to fail to pursue some investments for expansion than otherwise.

Of course, the lemons premium can vary both across firms' size and over time for the same firm. Regarding firm size, it is reasonable to expect that smaller firms face more severe financial constraints since they do not have the reach or visibility that larger firms have and therefore investors have difficulties in screening the quality of projects. The same type of relationship is expected when it comes to firm age, since over time firms develop relationships with suppliers of 
external finance, who build up knowledge on firms' and management quality, reducing information asymmetries - note that if a firm has just been created, not much information is available to potential investors (see Carreira and Silva, 2010, for a survey of the empirical literature). If asymmetric information problems become less severe, the upward-sloping section of supply schedule in Figure 1 will shift downward toward the horizontal schedule of perfect capital market.

When it comes to compare financial constraints in manufacturing and in services as a whole, it is not clear whether significant differences in the severity of such constraints should be expected. On the one hand, services firms will require, on average, a lower initial investment and a lower subsequent investment for expansion than manufacturing firms, so we would expect lower constraints for the former. On the other, for most services, the main input is human and not physical capital, while output is of an intangible nature, both subject to higher information asymmetries and increasing difficulty to be used as collateral when resorting to external finance. Figure 2 illustrates the demand and supply schedules for each sector. As can be seen, differences in financial constraints between manufacturing and services firms can arise (i.e. $\left.I_{\text {Man }}^{p}-I_{\text {Man }}^{f} \neq I_{\text {Ser }}^{p}-I_{\text {Ser }}^{f}\right)$, depending on the magnitude of the elasticity of demand and supply schedules. Our first hypothesis is therefore the following:

(H1) The level of financial constraints is different across sectors.

\section{Figure 2. Financial constraints in manufacturing and services sectors}

\section{Cost of funds}

Rate of return

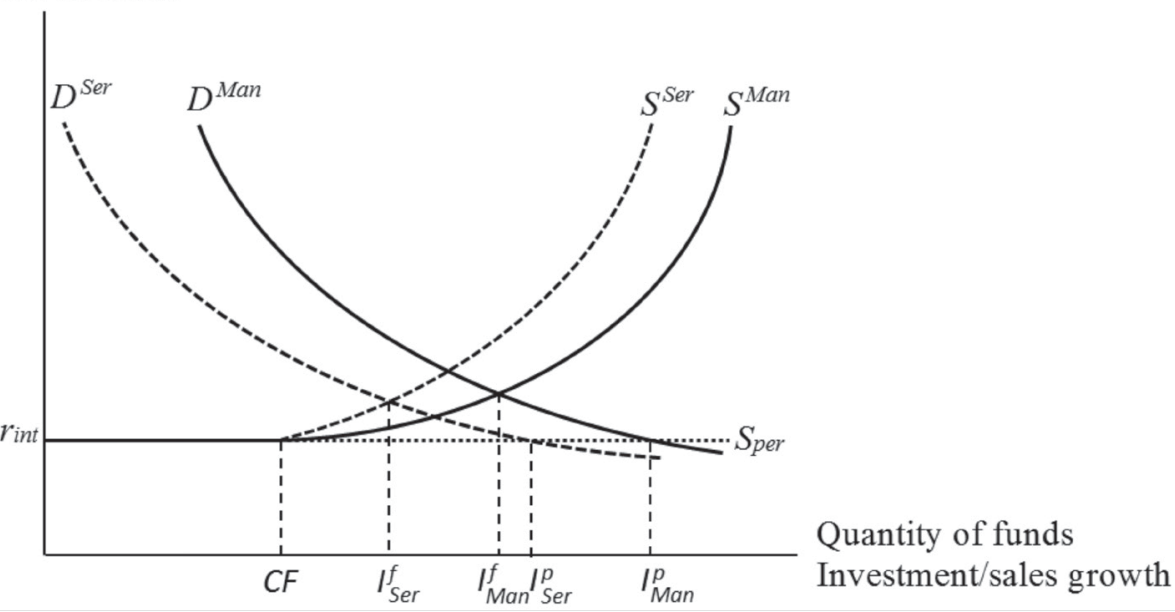

Note: The superindices/subindices Man and Ser denote manufacturing and services, respectively.

Differences among manufacturing and services firms regarding the type of capital (physical capital, which can easily be collateralized vs. human capital, which may lead to more pronounced learning effects) required in the production process can affect the expected inverse relationship between financial constraints and firm size and age. Specifically, manufacturing (services) firms are relatively more physical (human) capital-intensive than services (manufacturing) firms, thus, a stronger inverse relationship between financial constraints and size (age) is likely in manufacturing (services). This argument leads us to formulate the following hypotheses: 
(H2) There is an inverse relationship between financial constraints and firm size and age, which is robust to sector disaggregation.

(H3) The age effect is stronger in services firms than in manufacturing firms, while the size effect is weaker.

\section{Empirical strategy}

\subsection{Data}

To conduct our empirical analysis, we use an unbalanced panel of Portuguese manufacturing and services firms (CAE-classification of economic activities, Rev.2.1, from 15 to 37 and 50 to 93 , respectively) covering the period 1996-2004. ${ }^{3}$ The raw data is drawn from the combination of two statistical data sources, both run by the Portuguese Statistical Office (INE): Inquérito às Empresas Harmonizado (IEH), which is an annual business survey with information on balance sheets; and Ficheiro de Unidades Estatísticas (FUE) a file that contains, inter al, firm size, age and the main economic activity of all Portuguese firms. The longitudinal dimension of the panel, required for our analysis, was constructed using the firm (unique) identification code.

The IEH survey comprises all firms operating in Portugal with more than 100 employees, plus a representative random sample of firms with 20 to 99 employees - the sample is representative (at the 3-digit level), both in terms of employment size and sales. ${ }^{4}$ Given the number of observations, we excluded from the dataset tobacco products, and coke and refined petroleum products. We also excluded financial industry-inclusion of this sector would obviously bias the estimation favouring unconstrained firms. In total, we have, for the period 1996-2004, an unbalanced panel of 22,651 firms and a total of 86,455 year-firm observations.

\subsection{Measuring financial constraints}

Financial constraints are not directly observable, thus empirical research relies on indirect measures. We defined in Section 2 financial constraints as the inability of a firm to raise the necessary amount of funds to finance its investments for expansion. However, due to the abstract nature of this definition, there is no clear methodology to determine whether firms are financially constrained and, therefore, the correspondent degree. In fact, since the seminal work of Fazzari et al. (1988), who introduced the investment to cash-flow sensitivity approach, the empirical literature has struggled to find consistent methodologies to measure such constraints (see Silva and Carreira, 2012, for a survey).

\subsubsection{The Cash-Cash Flow Sensitivity approach}

Analysing firms' demand for cash, Almeida et al. (2004) claim that the level of financial constraints can be measured by the sensitivity of cash stock to cash flow-hereafter CCFS. The rationale is that, while constrained firms need to save cash out of cash flows in order to take advantage of future investment opportunities, unconstrained firms do not, as they are able to resort to external finance. Meanwhile, firms that hold cash incur in opportunity costs associated with present investment opportunities. As a result, only constrained firms will need to optimize their cash stocks over time in order to maximize their profits and hedge against future shocks by holding cash. Therefore, one can expect that estimates on the sensitivity of cash stocks to cash-flow would be positive and significant for constrained firms, while no such relation should be expected for unconstrained ones. Examples using this approach include Khurana et al. (2005), who examined a panel of firms from

3 At 2-digit level, there is a direct correspondence between the Portuguese Classification of Economic Activities (CAE Rev. 2.1) and both the European Community NACE Rev. 1.1 and the United Nations ISIC Rev. 3.1 classifications. 4 We note that firms with less than 20 employees represent about $71 \%$ of Portuguese manufacturing firms, but only 16 and $17 \%$ of total employment and production, respectively (average over the period 1996-2004; source: OECD database). 
35 countries between 1994-2002; Han and Qu (2006), who analysed USA publicly traded companies from 1997 to 2002; Lin (2007), who studied publicly traded Taiwanese firms over the period 1990-2004; and Pál and Ferrando (2010), who compared Euro-area firms between 1994 and 2003.

The financial nature of the cash stock variable should, in principle, work as a shield against investment opportunities hidden in cash-flow because it is not expected that firms will increase their cash stocks if cash-flow signals a newbetter investment opportunity, unless they are financially constrained. However, Acharya et al. (2007) show that financially constrained firms will tend to use cash to increase cash stocks if their hedging needs are high. Conversely, if their hedging needs are low, they will instead use cash to reduce debt. Therefore one might find firms whose propensity to save cash out of cash flow is low, even if they are financially constrained. Consequently, controlling for investment opportunities in empirical model is necessary. We use sales growth $\left(\Delta y_{i t}\right)$ as a proxy of investment opportunities. ${ }^{5}$

Although in the original paper Almeida et al. (2004) assumed that cash is the only way to transfer resources across time, in a subsequent research (Almeida et al., 2011) they pointed out that since holding cash is not the only form of inter-temporal allocation of capital, CCFS may actually be negative for constrained firms (Riddick and Whited, 2009) since firms may invest in relatively liquid assets, other than cash. As a result, we try to control for this effect by including change in non-cash net working capital $\left(\Delta N W C_{i t}\right)$ and financial investments $\left(F I N I_{i t}\right)$ variables.

In the spirit of Lin (2007), we also replace in the original Almeida et al.'s model the variation of short term-debt by the sum of net debt and equity issuances $\left(I S S_{i t}\right)$, and interest rate variation $\left(\Delta I N T_{i t}\right)$. The former modification is due to the fact that debt and equity issuances, while being a signal of easier access to external funds, might have a significant impact upon cash stocks (by accounting procedures). With respect to the latter, firms may decide to reduce their borrowings or pay back debt, according to expected interest expenses. However, instead of benchmark interest rates variations, we use variations of interest paid, which allows for firm variation, thus can also be seen as a form of credit rating.

Accordingly, we employ the following modified empirical model of Almeida et al. (2004, 2011):

$\Delta C S_{i t}=\beta_{1} C F_{i t}+\beta_{2} \Delta y_{i t}+\beta \ln S_{i t}+\beta_{4} I_{i t}+\beta_{5} \Delta N W C_{i t}+\beta_{6} I S S_{i t}+\beta_{7} \Delta I N T_{i t}+\beta_{8} F I N I_{i t}+T+\varepsilon_{i t}$

where $\Delta C S_{i t}$ is the variation in cash stocks for firm $i$ in period $t, C F_{i t}$ is the cash-flow, $\ln S_{i t}$ is the log of total assets, $I_{i t}$ is the investment, $T$ are the year dummies, and $e_{i t}$ the error term. With the exception of $S_{i t}$, all variables are scaled by total assets.

The financial and investment covariates are endogenous, so there is a need to estimate the model using instrumental variables (General Method of Moments, GMM) to control for unobserved firm-level heterogeneity. The set of instruments includes twice lagged cash flow, twice lagged sales growth, lagged investment, lagged variation of noncash net working capital, two-digit industry indicators (for overall samples), size (measured as number of employees), lagged bond issuance, lagged variation in interest payments, and lagged financial investments. This specification is particularly useful, since it makes use of variables that, for services firms, are easy to obtain and do not entail visible measurement problems.

\subsubsection{The Hovakimian-Hovakimian index}

In order to provide robust findings, we additionally compute a modified version of the Hovakimian and Hovakimian (2009) index-hereafter HOV index. It is a time averaged, firm-specific measure that, in the spirit of the investment to cash-flow sensitivity (Fazzari et al., 1988), compares the time

5 In order to deal with the potentially problematic use of sales growth as a proxy for investment opportunities we tested the use of forward investment, $I_{i(t+1)}$, lead investment, $I_{i(t+1)}+I_{i(t+2)} / I_{i t}$, and forward sales growth, D $y_{i(t+1)}$ (Table A2 in Appendix). However, results do not change significantly and this modification implies a great loss of observations-there is a huge loss of 5,583 or 9,542 observations corresponding to the loss of 1,353 or 2,635 firms if using forward or lead investment, respectively; the same applies to the use of future sales growth. 
average of investment weighted by cash-flow, against the simple average investment. ${ }^{6}$ Accordingly, investment in years when cash-flow is higher receives a higher weight, which means that if a firm invests more (less) in years with higher cash flow, the HOV index will yield positive (negative) values. The reverse is also true. For methodological consistency, we adapt this index to the CCFS framework by substituting investment by variation of cash stocks. Thus, our HOV index captures the sensitivity of cash stocks to variations of cash-flow and is determined as follows:

$$
H O V_{i}=\sum_{t=1}^{n}\left(\frac{(C F / S)_{i t}}{\sum_{t=1}^{n}(C F / S)_{i t}} *\left(\frac{\Delta C S}{S}\right)_{i t}\right)-\frac{1}{n} \sum_{t=1}^{n}\left(\frac{\Delta C S}{S}\right)_{i t}
$$

where $n$ the number of annual observations for firm $i$. In order to avoid extreme negative values, all cash-flow observations with negative values are set to zero. ${ }^{7}$ The main drawback of this measure is that, it does not account for the possibility that the same firm faces different states of constraints along the timeline, that is, it is time invariant. Therefore, we are only able to do a cross-section analysis and, as a consequence, we need to additionally compute time averages of other variables of interest such as size and age.

\subsection{Testing size and age as proxies of financial constraints}

We measure firm size as number of employees instead of either sales or assets, since it is expected to be less correlated with short-term firm performance, due to the stickiness of the labour force. Accordingly, we split the sample into four size classes: firms with 20-50, 51-100, 101-250, and 251 or more employees (small, medium-small, medium-large, and large firms, respectively). The thresholds were adjusted from the European Commission firm size classification to the specificity of our dataset. ${ }^{8}$ The threshold 100 employees, for example, allows to distinguish within the 51-250 heterogeneous class the medium-small from medium-large firms. Additionally, it also deals with possible representativeness problems due to the fact that in our dataset firms with less than 100 employees are drawn randomly, while firms with more than 100 employees make up the population.

With respect to firm age, we create three age classes: younger than 10, 11-40, and over 40 years old (young, mature, and old firms, respectively). The first threshold allows to accommodate the dynamics of entry and exiting (Caves, 1998; Carreira and Teixeira, 2011a), thus distinguishing young from mature firms (see Carreira and Teixeira, 2011b, for more detailed justification about this threshold). A possible relative inertia of older firms (Hannan, 2005) or even a change in firm objectives (Coad, 2010), led us to define an upper class of old firms. ${ }^{9}$

We should note that there is a problem with size and age sample partition: we can compute the firm mean values disregarding the fact that a given firm may move across class groups over year; or we can assign the current value which implies that the same firm can be accounted for in different class groups over year. We chose the former solution. (We note that, for the estimation of CCFS upon these subsamples, we drop InS from the specification due to its correlation with SIZE.)

In order to examine the degree of financial constraints upon different size and age classes, we introduce in equation (2) cash-flow interactions terms:

6 Note that other firm-specific indexes such as for example the KZ index of Lamont et al. (2001) or the SA index of Hadlock and Pierce (2010) require either a self-assessed measure of constraints or management reports to estimate coefficients for the computation of the index, therefore being specific to the dataset used. We have no access to such qualitative information.

7 This is the same procedure as in Hovakimian and Hovakimian (2009). We also remove firms for which investment level is only observed once.

8 The European Commission sets upper thresholds at 10,50 and 250 employees for micro, small and medium enterprises, respectively.

9 The results are robust to different specifications-results available from authors on request. 
$\Delta C S_{i t}=\beta_{1} C F_{i t}+\alpha_{1} X+\alpha_{2} C F_{i t} * X+\beta_{2} \Delta y_{i t}+\beta_{3} I_{i t}+\beta_{4} \Delta N W C_{i t}+\beta_{5} I S S_{i t}+\beta_{6} \Delta I N T_{i t}+$

$\beta_{7} F I N I_{i t}+T+\varepsilon_{i t}$

where $X$ is the size (age) dummies as well as, to test the nonlinearity hypothesis, $S I Z E$ and $S I Z E^{2}$ ( $A G E$ and $A G E^{2}$ ).

In line with the Size-Age index - hereafter SA index-of Hadlock and Pierce (2010), we also test if there is a non-linear relationship between size (age) and HOV index using the following model:

$H O V_{i}=\beta_{0}+\theta_{1} \overline{S I Z E}_{i}+\theta_{2} \overline{\operatorname{SIZE}}_{i}^{2}+\alpha_{1} \overline{A G E}_{i}+\alpha_{2} \overline{A G E}_{i}^{2}+\varepsilon_{i}$

where $\overline{S I Z E}_{i}$ and $\overline{A G E}_{i}$ are firm time average values of size and age, respectively (Hadlock and Pierce (2010) use total assets instead of number of employees, but as discussed above we prefer the latter).

\section{Empirical results}

\subsection{Summary statistics}

Table 1 summarises the main variables used in the empirical analyse, while descriptive statistics for the overall sample, as well as for manufacturing and services sectors, are presented in Table 2. A striking contrast between both sectors is given by the different mean cash stocks variation-for manufacturing firms, variation in cash stocks is only about $11 \%$ of the variation for services firms. Remarkable differences are also found with respect to the mean sales growth (higher for services firms), number of employees (services firms are larger), as well as in terms of age (manufacturing firms are older). In fact, both parametric mean and variance equality tests (t and $\mathrm{F}$ tests, respectively) as well as the non-parametric two sample Kolmogorov-Smirnov test for equality of distributions strongly reject the null hypothesis (at $1 \%$ significance level). Additionally, when we perform these tests for other selected variables, we cannot reject that differences exist between manufacturing and services, except in the cases of debt and equity issuances and variation of interest paid. ${ }^{10}$

Since most of the variables analysed do not follow a normal distribution, we compute Spearman's rank correlation coefficients and the respective confidence intervals (Table 3 ). Significance levels were set at the $1 \%$ level of significance and results are robust to Kendall's $t$. We find that while the association between changes in cash stocks and both cash-flow and sales growth is not different between sectors, the association between the former and investment (as well as financial investments) is only significantly negative for services firms. Nevertheless, the negative correlation between cash stock variation and investment, financial investments as well as variations of non-cash net working capital are as expected. Moreover, the correlation between cash-flow and debt and equity issuances is negative, possibly indicating that either when there is a shortage in internal funds firms resort to issuances or, on the contrary, when firms have large cash flows they use them to reduce debt.

Furthermore, whereas for manufacturing firms there is a strongly significant positive association between total assets and both cash-flow and investment, this association is negative and strongly significant for the case of services. Additionally, the positive association between cash-flow and investment is stronger for the case of manufacturing firms. Even though these relations are unconditional (and relatively small for the case of total assets), this may well be associated with differences in cost structures. 


\section{Table 1. Variables description}

\begin{tabular}{|l|l|}
\hline Variables & Description \\
\hline Assets $(S)$ & Inflation-adjusted total assets. \\
\hline Investment $(I)$ & Gross investment in plant, property and equipment. \\
\hline Output $(Y)$ & Total sales and services. \\
\hline Cash- flow $(C F)$ & Net income before taxes plus depreciation. \\
\hline Cash stock $(C S)$ & Total cash holdings. \\
\hline Investment Opportunities $(\Delta y)$ & $\begin{array}{l}\text { Since we do not have financial market information that would allow us } \\
\text { to compute Tobin's } Q \text {, we use sales growth to proxy for investment } \\
\text { opportunities. }\end{array}$ \\
\hline Debt and equity issuances $(I S S)$ & $\begin{array}{l}\text { Sum of debt and equity issuances. For the year 2001 equity issuances } \\
\text { are reported as missing. The reason lies in legal changes that took } \\
\text { place with the introduction of the Euro (most firms adjusted their } \\
\text { equity not necessarily meaning issuing equity). }\end{array}$ \\
\hline Non-cash net working capital $(N W K)$ & Difference between non-cash current assets and current liabilities. \\
\hline Variation of interest paid $(\Delta I N T)$ & $\begin{array}{l}\text { Variation of interest paid by firms, which may also reflect a firm- } \\
\text { specific rating. }\end{array}$ \\
\hline Financial investments $(F I N I)$ & Firms' financial investments. \\
\hline Size (SIZE) & number of employees. \\
\hline
\end{tabular}

Notes: All variables of interest were winsorized at $1 \%$ level in order to avoid problems with outliers in the estimation procedures. Deflators used include the Industrial Production Price Index and Labour Cost Index, both drawn from INE, and the GDP deflator, drawn from the Portuguese Central Bank. Nevertheless, no deflators were used when a variable was constructed as a ratio of two nominal values (normalized). In such cases we assume that the price growth rates are the same.

Table 2. Descriptive statistics

\begin{tabular}{|c|c|c|c|}
\hline Variables & Overall & Manufacturing & Services \\
\hline$\Delta C S_{i t}$ & $0.0021(0.062)$ & $0.0002(0.057)$ & $0.0043(0.068)$ \\
\hline$C F_{i t}$ & $0.0842(0.089)$ & $0.0856(0.089)$ & $0.0825(0.090)$ \\
\hline$\Delta y_{i t}$ & $0.0365(0.288)$ & $0.0185(0.245)$ & $0.0572(0.329)$ \\
\hline $\ln S_{i t}$ & $15.5066(1.402)$ & $15.5314(1.325)$ & $15.4779(1.486)$ \\
\hline$I_{i t}$ & $0.0622(0.081)$ & $0.0645(0.079)$ & $0.0596(0.084)$ \\
\hline$\Delta N W C_{i t}$ & $-0.0472(0.167)$ & $-0.0536(0.161)$ & $-0.0397(0.173)$ \\
\hline$I S S_{i t}$ & $0.0306(0.157)$ & $0.0295(0.150)$ & $0.0320(0.164)$ \\
\hline$\Delta I N T_{i t}$ & $-0.0006(0.007)$ & $-0.0007(0.007)$ & $-0.0005(0.007)$ \\
\hline Finl $_{i t}$ & $0.0392(0.090)$ & $0.0366(0.082)$ & $0.0423(0.097)$ \\
\hline$S I Z E_{i t}$ & $170.144(490.21)$ & $157.052(265.54)$ & $185.259(660.26)$ \\
\hline$A G E_{i t}$ & 26.855 (17.739) & 28.039 (17.880) & $25.489(17.476)$ \\
\hline Observations & 15,441 & 8,274 & 7,167 \\
\hline Number of firms & 4,255 & 2,247 & 2,006 \\
\hline
\end{tabular}

Notes: Mean values and standard deviations, given in parentheses, of the main variables used in the empirical analyses. The variables are scaled by total assets with the exception of $S_{i t}, S I Z E_{i t}$ and $A G E_{i t}$,

Finally, regarding firm size and age, we should note that even though we find a positive and significant correlation coefficient for manufacturing firms, this is not the case for services firms. 
Interestingly, we find no statistical significant association between these variables and variation of cash stocks, except for the case of age in the overall sample. Surprisingly, while cash-flow is always positively related to size, it is strongly negatively related to firm age.

\section{Table 3. Spearman's rank correlation matrices for manufacturing and services}

\begin{tabular}{|c|c|c|c|c|c|c|c|c|c|c|}
\hline Variables & $\mathrm{DCS}_{i t}$ & $C F_{i t}$ & $D y_{i t}$ & $\ln S_{i t}$ & $I_{\text {it }}$ & $\mathrm{DNWC}_{i t}$ & $I S S_{i t}$ & $\mathrm{DINT}_{\text {it }}$ & $F_{I N I}{ }_{i t}$ & $S_{I Z E_{i t}}$ \\
\hline \multicolumn{11}{|l|}{ a) Overall } \\
\hline $\mathrm{CF}_{\text {it }}$ & $0.0831^{*}$ & 1.00 & & & & & & & & \\
\hline$\Delta y_{i t}$ & $0.1178^{*}$ & $0.2494^{*}$ & 1.00 & & & & & & & \\
\hline $\operatorname{lnS} S_{\text {it }}$ & 0.0009 & $-0.0292^{*}$ & $0.0464^{\star}$ & 1.00 & & & & & & \\
\hline $\mathrm{I}_{\text {it }}$ & $-0.0291^{*}$ & $0.3091^{*}$ & $0.1613^{*}$ & -0.0051 & 1.00 & & & & & \\
\hline$\Delta N W C_{i t}$ & $-0.2524^{\star}$ & 0.0186 & $0.0290^{\star}$ & $0.0450^{*}$ & $-0.2816^{\star}$ & 1.00 & & & & \\
\hline $\mathrm{ISS}_{\text {it }}$ & $0.1260^{\star}$ & $-0.1668^{*}$ & $0.2028^{*}$ & $0.0519^{\star}$ & $0.2288^{*}$ & $-0.1576^{*}$ & 1.00 & & & \\
\hline$\Delta I N T_{i t}$ & -0.0088 & $-0.0805^{*}$ & $0.1189^{\star}$ & 0.0141 & $0.0847^{\star}$ & -0.0181 & $0.2268^{*}$ & 1.00 & & \\
\hline $\mathrm{FINI}_{\text {it }}$ & -0.0222 & $-0.0629^{\star}$ & $-0.0335^{*}$ & $0.3945^{\star}$ & $-0.0268^{*}$ & -0.0054 & 0.0045 & -0.0011 & 1.00 & \\
\hline $\mathrm{SIZE}_{\text {it }}$ & 0.0003 & $0.0659^{*}$ & $0.0728^{*}$ & $0.5852^{*}$ & $0.1069^{*}$ & $-0.0486^{*}$ & $0.0245^{\star}$ & 0.0079 & $0.2434^{*}$ & 1.00 \\
\hline $\mathrm{AGE}_{\mathrm{it}}$ & $-0.0243^{\star}$ & $-0.0929^{*}$ & $-0.1183^{\star}$ & $0.1231^{*}$ & $-0.0697^{\star}$ & 0.0191 & $-0.0456^{\star}$ & -0.0186 & $0.2417^{\star}$ & $0.0647^{\star}$ \\
\hline \multicolumn{11}{|c|}{ b) Manufacturing } \\
\hline $\mathrm{CF}_{\text {it }}$ & $0.0834^{*}$ & 1.00 & & & & & & & & \\
\hline$\Delta y_{i t}$ & $0.1173^{*}$ & $0.2782^{*}$ & 1.00 & & & & & & & \\
\hline $\operatorname{lnS} S_{\text {it }}$ & 0.0082 & $0.0520^{*}$ & $0.0648^{*}$ & 1.00 & & & & & & \\
\hline $\mathrm{I}_{\text {it }}$ & -0.0068 & $0.3291^{*}$ & $0.1883^{*}$ & $0.0362^{*}$ & 1.00 & & & & & \\
\hline$\Delta N W C_{i t}$ & $-0.2242^{*}$ & 0.0175 & $0.0372^{*}$ & $0.0423^{*}$ & $-0.2779^{\star}$ & 1.00 & & & & \\
\hline $\mathrm{ISS}_{\mathrm{it}}$ & $0.1049^{*}$ & $-0.1712^{*}$ & $0.1735^{\star}$ & 0.0228 & $0.2471^{*}$ & $-0.1407^{\star}$ & 1.00 & & & \\
\hline$\Delta I N T_{i t}$ & -0.0074 & $-0.0760^{*}$ & $0.1230^{*}$ & 0.0005 & $0.0836^{*}$ & -0.0099 & $0.2250^{*}$ & 1.00 & & \\
\hline $\mathrm{FINI}_{\text {it }}$ & 0.0007 & $-0.0462^{*}$ & -0.0136 & $0.4364^{\star}$ & -0.0243 & -0.0077 & 0.0096 & -0.0086 & 1.00 & \\
\hline SIZE $_{\text {it }}$ & -0.0041 & $0.0672^{*}$ & $0.0347^{*}$ & $0.6782^{*}$ & $0.0629^{*}$ & -0.0247 & -0.0143 & -0.0111 & $0.3225^{\star}$ & 1.00 \\
\hline $\mathrm{AGE}_{\mathrm{it}}$ & -0.0255 & $-0.1146^{*}$ & $-0.1057^{\star}$ & $0.1347^{\star}$ & $-0.0948^{*}$ & 0.0167 & $-0.0418^{\star}$ & -0.0182 & $0.2394^{*}$ & $0.1248^{*}$ \\
\hline \multicolumn{11}{|c|}{ c) Services } \\
\hline $\mathrm{CF}_{\text {it }}$ & $0.0862^{*}$ & 1.00 & & & & & & & & \\
\hline$\Delta y_{i t}$ & $0.1153^{*}$ & $0.2324^{*}$ & 1.00 & & & & & & & \\
\hline $\operatorname{lnS} S_{\text {it }}$ & -0.0074 & $-0.1119^{*}$ & 0.0293 & 1.00 & & & & & & \\
\hline $\mathrm{I}_{\text {it }}$ & $-0.0431^{*}$ & $0.2749^{*}$ & $0.1541^{*}$ & $-0.0534^{*}$ & 1.00 & & & & & \\
\hline$\Delta N W C_{i t}$ & $-0.2860^{*}$ & 0.0302 & 0.0139 & $0.0492^{*}$ & $-0.2731^{*}$ & 1.00 & & & & \\
\hline $\mathrm{ISS}_{\mathrm{it}}$ & $0.1447^{\star}$ & $-0.1619^{*}$ & $0.2292^{*}$ & $0.0805^{\star}$ & $0.2159^{*}$ & $-0.1755^{\star}$ & 1.00 & & & \\
\hline$\Delta I N T_{i t}$ & -0.0111 & $-0.0840^{*}$ & $0.1131^{*}$ & 0.0293 & $0.0911^{*}$ & -0.0295 & $0.2284^{\star}$ & 1.00 & & \\
\hline $\mathrm{FINI}_{\text {it }}$ & $-0.0448^{*}$ & $-0.0812^{*}$ & $-0.0529^{*}$ & $0.3537^{\star}$ & $-0.0322^{*}$ & -0.0028 & -0.0002 & 0.0068 & 1.00 & \\
\hline $\mathrm{SIZE}_{\text {it }}$ & 0.0124 & $0.0503^{*}$ & $0.1330^{*}$ & $0.5004^{*}$ & $0.1161^{*}$ & $-0.0494^{*}$ & $0.0624^{*}$ & $0.0330^{*}$ & $0.1709^{*}$ & 1.00 \\
\hline$A G E_{i t}$ & -0.0204 & $-0.0828^{*}$ & $-0.1171^{\star}$ & $0.1151^{*}$ & $-0.0673^{*}$ & $0.0355^{\star}$ & $-0.0486^{\star}$ & -0.0155 & $0.2477^{\star}$ & -0.0216 \\
\hline
\end{tabular}

Notes: Rank correlation coefficients were calculated using Sidak's adjustment. * denotes statistical significance at the .01 level.

\subsection{Differences across sectors}

As can be seen in Table 4, all regressions of model (2) report positive and significant sensitivity of cash to cash-flow. In column (1), which reports the results for the overall sample, the cash flow coefficient is significantly different from zero (at $1 \%$ significance level) - we note that if firms are financially unconstrained we expected the cash flow coefficient to be no significantly different from zero. The estimated CCFS is 0.159 , implying that Portuguese firms save, on average, about 16 cents out of each Euro of cash flow, which is symptomatic of the presence of financial constraints. This figure is 
comparable to those reported by Acharya et al. (2007) for a large sample of USA manufacturing firms, in the period 1971-2001, where a constrained firm retains 0.142 to 0.220 dollars as cash.

\section{Table 4. Cash-Cash Flow Sensitivity estimation for manufacturing and services sectors}

\begin{tabular}{|c|c|c|c|}
\hline Variables & $\begin{array}{l}\text { Overall } \\
\text { (1) }\end{array}$ & $\begin{array}{l}\text { Manufacturing } \\
\text { (2) }\end{array}$ & $\begin{array}{l}\text { Services } \\
\text { (3) }\end{array}$ \\
\hline \multirow[t]{2}{*}{$C F_{i t}$} & $0.159^{* \star *}(0.018)$ & $0.107^{\star \star \star}(0.021)$ & $0.226^{* \star \star}(0.032)$ \\
\hline & {$[0.124 ; 0.194]$} & {$[0.067 ; 0.147]$} & {$[0.164 ; 0.288]$} \\
\hline \multirow{2}{*}{$\Delta y_{i t}$} & $0.014^{* * *}(0.003)$ & $0.018^{* \star *}(0.004)$ & $0.011^{* *} \quad(0.005)$ \\
\hline & {$[0.008 ; 0.021]$} & {$[0.009 ; 0.026]$} & {$[0.002 ; 0.020]$} \\
\hline \multirow[t]{2}{*}{$\ln S_{i t}$} & $0.016^{\star \star *}(0.004)$ & $0.019^{\star \star \star}(0.005)$ & $0.016^{* \star}(0.007)$ \\
\hline & {$[0.008 ; 0.025]$} & {$[0.009 ; 0.030]$} & {$[0.003 ; 0.029]$} \\
\hline \multirow[t]{2}{*}{$I_{i t}$} & $-0.202^{\star \star \star}(0.012)$ & $-0.143^{\star \star \star}(0.014)$ & $-0.270^{\star * \star}(0.020)$ \\
\hline & {$[-0.225 ;-0.178]$} & {$[-0.170 ;-0.115]$} & {$[-0.309 ;-0.231]$} \\
\hline \multirow[t]{2}{*}{$\Delta N W C_{i t}$} & $-0.124^{\star * \star}(0.006)$ & $-0.109^{\star \star \star}(0.008)$ & $-0.140^{\star * *}(0.009)$ \\
\hline & {$[-0.136 ;-0.112]$} & {$[-0.124 ;-0.094]$} & {$[-0.158 ;-0.121]$} \\
\hline \multirow[t]{2}{*}{$I S S_{i t}$} & $0.078^{\star * *}(0.006)$ & $0.063^{\star \star *}(0.008)$ & $0.094^{\star * *}(0.010)$ \\
\hline & {$[0.066 ; 0.091]$} & {$[0.048 ; 0.078]$} & {$[0.075 ; 0.114]$} \\
\hline \multirow[t]{2}{*}{$\Delta I N T_{i t}$} & $\begin{array}{ll}-0.126 & (0.104) \\
\end{array}$ & $-0.054 \quad(0.130)$ & $-0.220 \quad(0.166)$ \\
\hline & {$[-0.329 ; 0.077]$} & {$[-0.308 ; 0.201]$} & {$[-0.544 ; 0.105]$} \\
\hline \multirow[t]{2}{*}{$F I N I_{i t}$} & $-0.125^{\star \star \star}(0.018)$ & $-0.093^{\star \star \star}(0.025)$ & $-0.159^{\star \star \star}(0.027)$ \\
\hline & {$[-0.161 ;-0.089]$} & {$[-0.141 ;-0.045]$} & {$[-0.212 ;-0.105]$} \\
\hline Observations & 13,874 & 7,590 & 6,256 \\
\hline No. of firms & 4,322 & 2,277 & 2,043 \\
\hline Hansen p-val. & 0.463 & 0.430 & 0.751 \\
\hline R-squared & 0.158 & 0.131 & 0.195 \\
\hline
\end{tabular}

Notes: Regression of model (2). Estimations also include year dummies. Robust standard errors in parentheses; $95 \%$ confidence intervals in brackets. ${ }^{* \star},{ }^{* \star}$, and ${ }^{*}$ denote statistical significance at the $.01, .05$, and .10 levels, respectively. Results do not change significantly with industry dummies (Table A1) or with different proxies for investment opportunities (Table A2). Further test statistics available from the authors.

The comparison between manufacturing and services (columns (2) and (3)) indicates that firms operating in the former are not as severely affected by financial constraints as firms in the latter. In fact, while manufacturing firms save, on average, around 11 cents out of each Euro of extra cash flow, services firms save 23 cents out of each Euro of extra cash flow-the estimates are both significant at the $1 \%$ level and statistically different at the $1 \%$ significance level. ${ }^{11}$ Another striking difference can be found on the impact of size (total assets) on firms' cash policy-the magnitude of the size effect is smaller for services than manufacturing firms. This may be due to the fact that manufacturing firms have a higher minimum efficiency scale and incur in larger both initial investment and subsequent investment for expansion in comparison with services firms. Accordingly, the liquidity needs are larger in the former. Finally, except for sales growth, the impact of the remaining explanatory variables is greater for the case of services, meaning that these firms are, in general more cautious with their cash policy than manufacturing firms.

These results are robust with both year and industry dummies (Table A1 in Appendix). Furthermore, using different proxies for investment opportunities (Table A2) results do not change significantly and we still find that the CCFS of manufacturing firms is lower than that of services. Moreover, when we test interactions of cash-flow with sector dummies, we also find that both manufacturing and services sectors coefficients are positive, significant and larger for services (0.129 and 0.211 , respectively).

11 The reported $\mathrm{R}^{2}$ statistics are within the expected range in these models. 
Alternatively, we compute the HOV index as in model (3) and compare the distribution for the different sectors (Table 5). ${ }^{12}$ Firstly, the median and mean are higher for the services sample, even though there is larger variation. Secondly, services firms' HOV index distribution is more skewed to the right, as well as there is an higher percentage of observations above zero-within the CCFS interpretation, firms that save more cash in years of higher cash-flows are financially constrained-of $54.2 \%$ against $52.7 \%$ in manufacturing. Thirdly, even though a formal Mann-Whitney test indicates that manufacturing and services medians are not statistically different at any level smaller than $12.5 \%$, a Kolmogorov-Smirnov test rejects the equality of distributions. Finally, a quantile-quantile plot of the HOV index values for each sector (Figure 3 ) indicates that the HOV index distribution for services is more dispersed, skewed and, most importantly, it reveals that for positive values of the index (i.e. firms that are financially constrained), services' HOV index distribution seems to dominate the manufacturing's HOV index distribution. On the whole, the comparison of the HOV index between these two sectors suggests that whenever present financial constraints tend to be higher for services firms.

Table 5. HOV index distribution

\begin{tabular}{|c|c|c|c|}
\hline & $\begin{array}{l}\text { Overall } \\
\text { (1) }\end{array}$ & $\begin{array}{l}\text { Manufacturing } \\
\text { (2) }\end{array}$ & $\begin{array}{l}\text { Services } \\
\text { (3) }\end{array}$ \\
\hline \multicolumn{4}{|c|}{ a) Percentiles } \\
\hline Min & -0.1618 & -0.1270 & -0.1618 \\
\hline 1 & -0.0226 & -0.0180 & -0.0251 \\
\hline 5 & -0.0065 & -0.0051 & -0.0078 \\
\hline 10 & -0.0030 & -0.0023 & -0.0037 \\
\hline 25 & -0.0006 & -0.0005 & -0.0007 \\
\hline 50 & 0.0000 & 0.0000 & 0.0001 \\
\hline 75 & 0.0010 & 0.0008 & 0.0012 \\
\hline 90 & 0.0047 & 0.0037 & 0.0054 \\
\hline 95 & 0.0094 & 0.0077 & 0.0108 \\
\hline 99 & 0.0286 & 0.0267 & 0.0313 \\
\hline Max & 0.1632 & 0.1270 & 0.1632 \\
\hline \multicolumn{4}{|c|}{ b) Statistics } \\
\hline Obs. & 9112 & 4406 & 4706 \\
\hline Mean & 0.0006 & 0.0005 & 0.0007 \\
\hline S.d. & 0.0088 & 0.0071 & 0.0102 \\
\hline Skew. & 2.3606 & 1.4108 & 2.5207 \\
\hline Kurt. & 82.5336 & 74.9682 & 73.7531 \\
\hline$\%$ Obs. $>0$ & $53.48 \%$ & $52.70 \%$ & $54.21 \%$ \\
\hline K-S p. & 0.000 & & \\
\hline M-W p. & 0.1254 & \multicolumn{2}{|c|}{$P($ Manuf. $>$ Serv $)=0.491$} \\
\hline
\end{tabular}

Notes: Distribution of the HOV index, as in equation (3), for the overall manufacturing and services samples. We report the minimum and maximum values (Min and Max, respectively), the mean (Mean), standard deviations (S.d.), skewness (Skew.), kurtosis (Kurt.), the percentage of observations above zero (\%Obs.>0), as well as the $\mathrm{p}$-values for the following non-parametric tests: Kolmogorov-Smirnov for equality of distribution (K-S p.), Mann-Whitney adjusted for ties (M-W p.) and the probability that manufacturing $\mathrm{HOV}$ values are larger than services values ( $\mathrm{P}$ (Manuf.>Serv))

12 We validate the use of the adapted HOV index to the cash management perspective by testing if CCFS estimation yields higher cash-flow estimates for higher HOV index levels. There is a clear increase in CCFS when we move from lower to higher quartiles of the index (Table A3 in Appendix). 


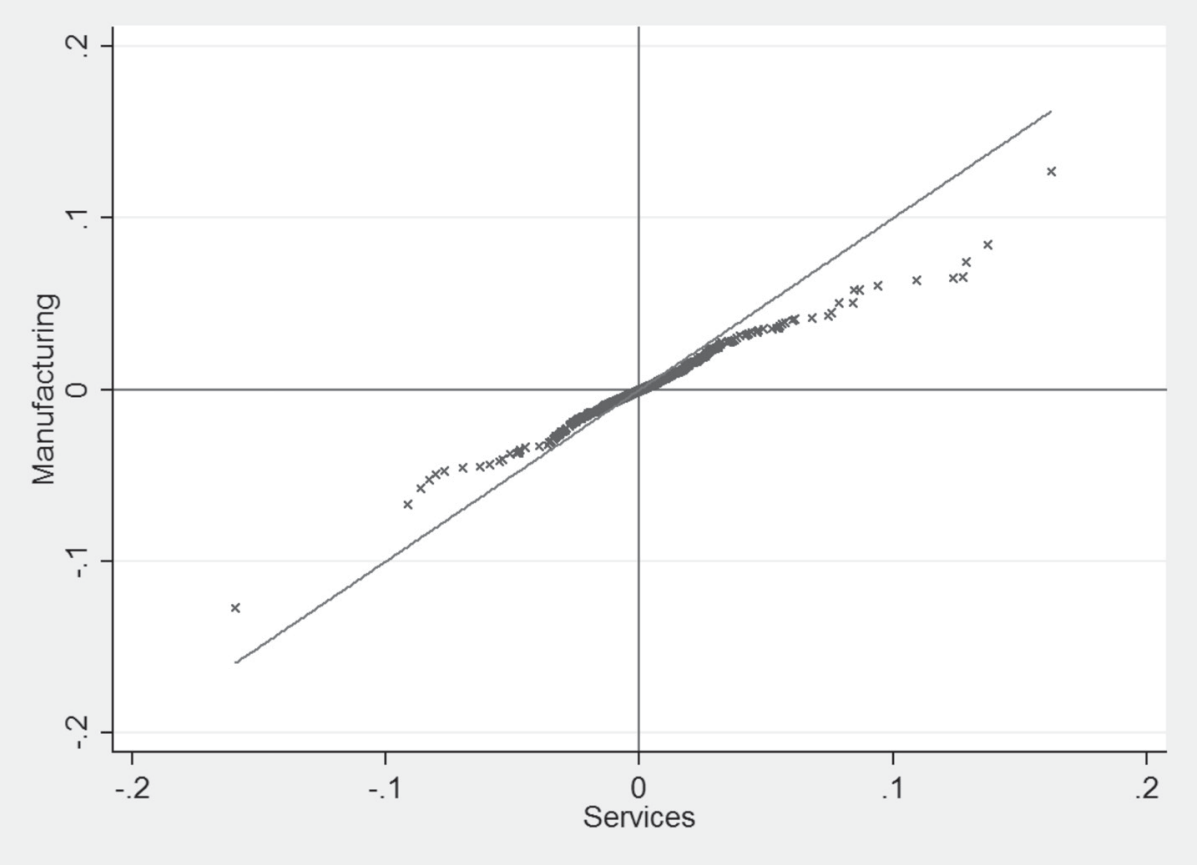

Notes: We plot the quantiles of the HOV index distribution (computed as in eq. 2), for Manufacturing against those in Services (vertically and horizontaly, respectively). Values above the vertical (horizontal) lines at $\mathrm{HOV}=0$ indicate that services

(manufacturing) firms save more cash in years of higher cash-flow, suggesting the presence of financial constraints. Values above (under) the symmetry line $(y=x)$ indicate higher HOV values for manufacturing (services) firms.

Overall, there is broad evidence in favour of $\mathrm{H} 1$, according to which the financial constraints are different between manufacturing and services sectors. Actually, these constraints tend to be higher for services than manufacturing firms.

\subsection{The relationship between size/age and financial constraints}

Table 6 reports the estimation results of the interactions between cash-flow and size and age class dummies. We find that while for the case of age the estimated interaction coefficients are always lower for older firms (columns (2), (4), and (6)), this is not the case for the size-cash flow interactions (columns (1), (3), and (5)). In fact, for services firms, we do not find the expected inverse relationship between size and financial constraints, since the estimated interaction coefficients decrease up to the medium-large size and then increases for larger firms (column (5)), which suggests a non-monotonic U-shaped relationship. 


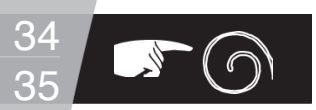

\section{Table 6. CCFS with size and age classes interaction terms}

\begin{tabular}{|c|c|c|c|c|c|c|}
\hline \multirow[t]{3}{*}{ Variables } & \multicolumn{2}{|l|}{ Overall } & \multicolumn{2}{|c|}{ Manufacturing } & \multicolumn{2}{|l|}{ Services } \\
\hline & Size & Age & Size & Age & Size & Age \\
\hline & (1) & (2) & (3) & (4) & (5) & (6) \\
\hline \multicolumn{7}{|l|}{$C F_{i t} \times \overline{S I Z E}_{i}$} \\
\hline \multirow[t]{2}{*}{ Small firms } & $0.230^{\star \star \star}$ & & $0.164^{* \star *}$ & & $0.297^{\star \star \star}$ & \\
\hline & $(0.030)$ & & $(0.038)$ & & $(0.045)$ & \\
\hline \multirow[t]{2}{*}{ Medium-small firms } & $0.163^{\star \star *}$ & & $0.147^{\star \star \star}$ & & $0.185^{\star \star \star}$ & \\
\hline & $(0.028)$ & & $(0.032)$ & & $(0.046)$ & \\
\hline \multirow[t]{2}{*}{ Medium-large firms } & $0.114^{* \star *}$ & & $0.084^{* \star *}$ & & $0.149^{* \star *}$ & \\
\hline & $(0.023)$ & & $(0.026)$ & & $(0.050)$ & \\
\hline \multirow[t]{2}{*}{ Large firms } & $0.132^{\star \star \star}$ & & 0.047 & & $0.241^{\star \star \star}$ & \\
\hline & $(0.030)$ & & $(0.037)$ & & $(0.050)$ & \\
\hline \multicolumn{7}{|l|}{$C F_{i t} \times \overline{A G E}_{i}$} \\
\hline \multirow[t]{2}{*}{ Young firms } & & $0.179^{\star \star \star}$ & & $0.132^{\star \star \star}$ & & $0.247^{\star \star \star}$ \\
\hline & & $(0.038)$ & & $(0.045)$ & & $(0.061)$ \\
\hline \multirow[t]{2}{*}{ Mature firms } & & $0.169^{\star \star \star}$ & & $0.114^{\star \star \star}$ & & $0.238^{\star \star \star}$ \\
\hline & & $(0.019)$ & & $(0.022)$ & & $(0.034)$ \\
\hline \multirow[t]{2}{*}{ Old firms } & & $0.125^{\star \star \star}$ & & $0.089^{\star *}$ & & $0.168^{\star \star}$ \\
\hline & & $(0.034)$ & & $(0.037)$ & & $(0.068)$ \\
\hline \multirow[t]{2}{*}{$\Delta y_{i t}$} & $0.015^{\star \star \star}$ & $0.015^{\star \star \star}$ & $0.020^{\star \star \star}$ & $0.020^{\star \star *}$ & $0.011^{\star *}$ & $0.011^{* *}$ \\
\hline & $(0.003)$ & $(0.003)$ & $(0.004)$ & $(0.004)$ & $(0.004)$ & $(0.004)$ \\
\hline \multirow[t]{2}{*}{$l_{i t}$} & $-0.201^{\star \star \star}$ & $-0.201^{\star \star \star}$ & $-0.141^{\star \star *}$ & $-0.140^{* \star *}$ & $-0.271^{\star \star \star}$ & $-0.271^{\star \star \star}$ \\
\hline & $(0.012)$ & $(0.012)$ & $(0.014)$ & $(0.014)$ & $(0.020)$ & $(0.020)$ \\
\hline \multirow[t]{2}{*}{$\Delta N W C_{i t}$} & $-0.123^{\star \star \star}$ & $-0.122^{\star \star \star}$ & $-0.106^{\star \star \star}$ & $-0.106^{\star \star \star}$ & $-0.141^{\star \star *}$ & $-0.140^{\star \star \star}$ \\
\hline & $(0.006)$ & $(0.006)$ & $(0.008)$ & $(0.008)$ & $(0.009)$ & $(0.009)$ \\
\hline \multirow[t]{2}{*}{$I S S_{i t}$} & $0.086^{* \star *}$ & $0.086^{\star \star \star}$ & $0.071^{\star \star \star}$ & $0.071^{* * *}$ & $0.103^{\star \star \star}$ & $0.102^{\star \star \star}$ \\
\hline & $(0.006)$ & $(0.006)$ & $(0.008)$ & $(0.007)$ & $(0.010)$ & $(0.010)$ \\
\hline \multirow[t]{2}{*}{$\Delta I N T_{i t}$} & -0.091 & -0.097 & -0.011 & -0.015 & -0.180 & -0.195 \\
\hline & $(0.103)$ & $(0.104)$ & $(0.130)$ & $(0.130)$ & $(0.165)$ & $(0.166)$ \\
\hline \multirow[t]{2}{*}{ FINI ${ }_{i t}$} & $-0.118^{\star \star \star}$ & $-0.116^{\star \star \star}$ & $-0.083^{\star \star \star}$ & $-0.079^{\star \star \star}$ & $-0.148^{\star \star \star}$ & $-0.148^{\star \star *}$ \\
\hline & $(0.018)$ & $(0.018)$ & $(0.024)$ & $(0.024)$ & $(0.027)$ & $(0.027)$ \\
\hline Observations & 13,874 & 13,874 & 7,590 & 7,590 & 6,256 & 6,256 \\
\hline Number of firms & 4,322 & 4,322 & 2,277 & 2,277 & 2,043 & 2,043 \\
\hline Hansen chi2 p-value & 0.473 & 0.364 & 0.533 & 0.499 & 0.277 & 0.308 \\
\hline R-squared & 0.158 & 0.156 & 0.129 & 0.127 & 0.196 & 0.193 \\
\hline
\end{tabular}

Notes: Regression of model (4), where $X$ corresponds to either size/age class dummies. Small, medium-small, medium-large and large firms are those with 20-50, 51-100, 101-250 and 251 or more employees, respectively. Young, mature and old firms are those younger than 10, 11-40 and over 40 years old, respectively. Estimations also include year dummies. Robust standard errors in parentheses. ${ }^{* \star *},{ }^{* \star}$, and ${ }^{*}$ denote statistical significance at the $.01, .05$, and .10 levels, respectively. Further test statistics available from the authors on request.We further investigate these relationships by testing the inclusion of size and age interaction (and its quadratic) terms (Table 7). For the case of the size variable, we find that in both the overall sample and manufacturing sector the estimates confirm the presence of an U-shaped relationship. All remaining interaction terms are not statistically different from zero at conventional levels. These results do question the well-accepted monotonic relationship between size and financial constraints. 


\section{Table 7. CCFS with size and age interaction terms}

\begin{tabular}{|c|c|c|c|}
\hline Variables & $\begin{array}{l}\text { Overall } \\
\text { (1) }\end{array}$ & $\begin{array}{l}\text { Manufacturing } \\
\text { (2) }\end{array}$ & $\begin{array}{l}\text { Services } \\
\text { (3) }\end{array}$ \\
\hline$C F_{i t}$ & $0.157^{\star \star \star}(0.047)$ & $0.104^{*} \quad(0.057)$ & $0.217^{\star \star \star}(0.076)$ \\
\hline$S I Z E_{i t}$ & $-0.000^{* *}(0.000)$ & $-0.000 \quad(0.000)$ & $-0.000^{*} \quad(0.000)$ \\
\hline$C F_{i t}{ }^{*} S I Z E_{i t}$ & $-0.000^{*} \quad(0.000)$ & $-0.000^{* *}(0.000)$ & -0.000 \\
\hline$C F_{i t}{ }^{*} S I Z E_{i t}{ }^{2}$ & $0.000^{\star \star *}(0.000)$ & $0.000^{* *} \quad(0.000)$ & $0.000 \quad(0.000)$ \\
\hline$A G E_{i t}$ & $0.000 \quad(0.002)$ & $0.001 \quad(0.002)$ & $\begin{array}{ll}-0.001 \quad(0.002) \\
\end{array}$ \\
\hline$C F_{i t}{ }^{*} A G E_{i t}$ & $0.003 \quad(0.002)$ & 0.004 & $0.002 \quad(0.004)$ \\
\hline$C F_{i t}{ }^{*} A G E_{i t}{ }^{2}$ & $-0.000 \quad(0.000)$ & $-0.000 \quad(0.000)$ & -0.000 \\
\hline$\Delta y_{i t}$ & $0.015^{\star \star \star}(0.003)$ & $0.020^{\star \star *}(0.004)$ & $0.011^{\star *}(0.005)$ \\
\hline$I_{i t}$ & $-0.196^{\star * *}(0.012)$ & $-0.139^{\star \star *}(0.014)$ & $-0.262^{\star * *}(0.020)$ \\
\hline$\Delta N W C_{i t}$ & $-0.122^{\star \star \star}(0.006)$ & 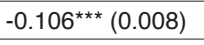 & 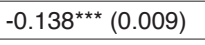 \\
\hline$I S S_{i t}$ & $0.084^{\star * *}(0.006)$ & $0.070^{\star \star *}(0.007)$ & $0.100^{\star * *}(0.010)$ \\
\hline$\Delta I N T_{i t}$ & $-0.061 \quad(0.105)$ & $0.029 \quad(0.132)$ & $-0.173 \quad(0.169)$ \\
\hline $\mathrm{FINI}_{i t}$ & $-0.116^{\star * *}(0.018)$ & $-0.081^{\star * *}(0.024)$ & $-0.150^{\star \star \star}(0.028)$ \\
\hline Observations & 13,724 & 7,527 & 6,169 \\
\hline Number of firms & 4,255 & 2,247 & 2,006 \\
\hline Hansen chi2 p-value & 0.882 & 0.380 & 0.970 \\
\hline R-squared & 0.157 & 0.132 & 0.193 \\
\hline
\end{tabular}

Notes: Regression of model (4), where $X$ corresponds to size, age and its square values. Estimations also include year dummies. Robust standard errors in parentheses. ${ }^{\star \star *},{ }^{\star \star}$, and * denote statistical significance at the $.01, .05$, and .10 levels, respectively. Results with $X$ corresponding only to either size or age (not different), as well as further test statistics are available from the authors on request.

Alternatively, we look at the relationship between the HOV index and size/age. Firstly, the spearman correlation coefficients yield negative but not statistically significant correlations (these results are available from authors upon request). Secondly, the results from a simple OLS regression of model (5) report an U-shaped relationship between size and constraints for the overall and manufacturing samples (Table 8, columns (1) and (2), respectively), while the size coefficients do not seem to be statistically significant at conventional levels in the services sector. ${ }^{13}$ Oddly none of the age coefficients are statistically significant. However, if we restrict our sample to positive $\mathrm{HOV}$ index values (that is, to firms that are financially constrained), we find an U-shaped relationship between financial constraints and size for all subsamples (columns (4) to (6)) and an U-shaped relationship between age and financial constraints for the overall and services subsamples. Finally, by estimating a simultaneous quantile regression, we found that while for lower quantiles there is an inverted U-shaped relationship between financial constraints and size/age, for higher quantiles, this relationship becomes U-shaped. ${ }^{14}$

\section{Concluding remarks}

This paper analyses whether the role of financial constraints differ across manufacturing and services sectors. Our results show that financial constraints are more severe for services than for

13 Note that this regression is run on a cross section that results from the computation of average time values of the variables of interest, given that the HOV index is a time average itself.

14 Simultaneous quantile regression, with 499 bootstrap replications, for the following quantiles: $5 ; 10 ; 15 ; 20$; $25 ; 30 ; 35 ; 40 ; 45 ; 50 ; 55 ; 60 ; 65 ; 70 ; 75 ; 80 ; 85 ; 90$, and 95. 
manufacturing firms. On the other hand, regarding firm size and age, distinct patterns arise across the two sectors. Indeed, the relationship between size and financial constraints is U-shaped for the case of services. In turn, for manufacturing we find some evidence suggesting an inverse relationship, although this finding is not robust to all scenarios. The relationship between age and financial constraints appears to be inverse in the case of services, but not in the case of manufacturing, for which we have mixed evidence.

\section{Table 8. Relationship of size and age with the HOV index}

\begin{tabular}{|c|c|c|c|c|c|c|}
\hline \multirow[t]{2}{*}{ Variables } & \multicolumn{3}{|l|}{ All firms } & \multicolumn{3}{|c|}{ Firms' financially constrained } \\
\hline & Overall & Manufacturing & Services & Overall & Manufacturing & Services \\
\hline & (1) & (2) & (3) & (4) & (5) & (6) \\
\hline$\overline{S I Z E}_{i}$ & $-0.473^{\star \star}$ & $-0.592^{\star *}$ & -0.415 & $-1.777^{\star \star *}$ & $-2.368^{\star \star *}$ & $-1.424^{\star \star *}$ \\
\hline & $(0.196)$ & $(0.286)$ & $(0.276)$ & $(0.299)$ & $(0.437)$ & $(0.409)$ \\
\hline$\overline{S I Z E}_{i}^{2}$ & $0.040^{* *}$ & $0.052^{*}$ & 0.034 & $0.141^{\star \star \star}$ & $0.202^{\star \star *}$ & $0.105^{\star \star \star}$ \\
\hline & $(0.018)$ & $(0.028)$ & $(0.025)$ & $(0.028)$ & $(0.043)$ & $(0.038)$ \\
\hline$\overline{A G E}_{i}$ & -0.217 & -0.052 & -0.293 & $-1.091^{\star \star *}$ & -0.563 & $-1.346^{\star *}$ \\
\hline & $(0.270)$ & $(0.272)$ & $(0.449)$ & $(0.371)$ & $(0.358)$ & $(0.606)$ \\
\hline$\overline{A G E}_{i}^{2}$ & 0.050 & 0.035 & 0.052 & $0.176^{\star \star \star}$ & $0.112^{\star}$ & $0.198^{\star *}$ \\
\hline & $(0.044)$ & $(0.047)$ & $(0.073)$ & $(0.061)$ & $(0.062)$ & $(0.099)$ \\
\hline Observations & 8,841 & 4,298 & 4,543 & 4,745 & 2,264 & 2,481 \\
\hline R-squared & 0.0093 & 0.0061 & 0.0111 & 0.0568 & 0.0527 & 0.0551 \\
\hline
\end{tabular}

Notes: Regression of model (5). Rescaled HOV index to the interval [0;100]. A firm is constrained if the non-scaled HOV index $>0$ (i.e. the value 49.79 in the rescaled index). Estimations also include year dummies. Robust standard errors in parentheses. Robust standard errors are in parentheses. ${ }^{* \star *},{ }^{* *}$, and ${ }^{*}$ denote statistical significance at the $.01, .05$, and .10 levels, respectively. Further test statistics available from the authors on request.Overall, size and age interplay with financial constraints in a rather non-trivial way. The results indicate that the hypothesis $\mathrm{H} 2$ ought to be rejected, while $\mathrm{H} 3$ cannot be easily rejected.

The relationship between size/age and financial constraints are thus very much open to discussion in future research, namely, the use of these variables as proxies for financial constraints. Firstly, it is not clear that, for aggregated samples, there is an inverse relationship between financial constraints and size/age. On the contrary, our results show that this relationship is non-linear. Secondly, depending on the sector being analysed, size or age may work as better proxies.

Our results are also relevant for policy making. In particular, policymakers should take into consideration the impact of sector specificities when designing policies to alleviate firms' financial constraints. Public financial support, that typically positively discriminates smaller, exporting or new firms, should also take into account the fact that financial constraints might be quite distinct across sectors.

\section{References}

Acharya, V.; Almeida H.; Campello, M. (2007) Is cash negative debt? A hedging perspective on corporate financial policies, Journal of Financial Intermediation, 16(4), 515-54.

Almeida, H.; Campello, M.; Weisbach, M. (2004) The cash flow sensitivity of cash, Journal of Finance, 59(4), 1777-804. 
Almeida, H.; Campello, M.; Weisbach, M. (2011) Corporate financial and investment policies when future financing is not frictionless, Journal of Corporate Finance, 17(3), 675-93.

Carpenter, R.E.; Petersen, B.C. (2002a) Is the growth of small firms constrained by internal finance? Review of Economics and Statistics, 84(2), 298-309.

Carpenter, R.E.; Petersen, B.C. (2002b) Capital market imperfections, high-tech investment, and new equity financing, Economic Journal, 112, F54-F72.

Carreira, C.; Silva, F. (2010) No Deep Pockets: Some stylized results on firms' financial constraints, Journal of Economic Surveys, 24(4), 731-53.

Carreira, C.; Teixeira, P. (2011a) Entry and exit as a source of aggregate productivity growth in two alternative technological regimes, Structural Change and Economic Dynamics, 22(2), 135-50.

Carreira, C. Teixeira, P. (2011b) The shadow of death: Analysing the pre-exit productivity of Portuguese manufacturing firms, Small Business Economics, 36(3), 337-51.

Caves, R.E. (1998) Industrial organization and new findings on the turnover and mobility of firms, Journal of Economic Literature, 36, 1947-82.

Coad, A. (2010) Investigating the exponential age distribution of firms, Economics: The OpenAccess, Open-Assessment E-Journal 4(17).

Demirgüç-Kunt, A.; Maksimovic, V. (1998) Law, finance and firm growth, Journal of Finance, 53, 2107-2137.

Fazzari, S.M.; Hubbard, R.G.; Petersen, B.C. (1988) Financing constraints and corporate investment, Brookings Papers on Economic Activity, 1988 (1), 141-95.

Hadlock, C.; Pierce, J. (2010) New Evidence on Measuring Financial Constraints: Moving beyond the KZ index, Review of Financial Studies, 23(5), 1909-1940.

Han, S.; Qiu, J. (2006) Corporate precautionary cash holdings, Journal of Corporate Finance, 13(1), 43-57.

Hannan, M.T. (2005) Ecologies of organizations: Diversity and identity, Journal of Economic Perspectives, 19(1), 51-70.

Higgins, R.C. (1977) How much growth a firm can afford? Financial Management, 6, 3-16.

Hovakimian, A.; Hovakimian, G. (2009), Cash Flow Sensitivity of Investment, European Financial Management, 15(1), 47-65.

Khurana, I.K.; Martin, X.; Pereira, R. (2005) Financial development and the cash flow sensitivity of cash, Journal of Financial and Quantitative Analysis, 41(4), 787-807.

Kukuk, M.; Stadler, M. (2001) Financing constraints and the timing of innovations in the German services sector, Empirica, 28(3), 277-92.

Lin, Y. (2007) The cash flow sensitivity of cash: Evidence from Taiwan, Applied Financial Economics, 17(12), 1013-24.

Pál, R.; Ferrando, A. (2010) Financing constraints and firms' cash policy in the Euro area, European Journal of Finance, 16(2), 153-71.

Riddick, L.; Whited, T. (2009) The Corporate Propensity to Save, Journal of Finance, 64(4), 1729-66.

Silva, F.; Carreira, C. (2012) Measuring firms' financial constraints: A rough guide, Notas Económicas, 36, 23-46. 
Appendix

Table A1. CCFS with industry and year dummies

\begin{tabular}{|c|c|c|c|c|c|c|}
\hline Variables & $\begin{array}{l}\text { Overall } \\
\text { (1) }\end{array}$ & $\begin{array}{l}\text { Manufacturing } \\
\text { (2) }\end{array}$ & $\begin{array}{l}\text { Services } \\
\text { (3) }\end{array}$ & $\begin{array}{l}\text { Overall } \\
\text { (4) }\end{array}$ & $\begin{array}{l}\text { Manufacturing } \\
\text { (5) }\end{array}$ & $\begin{array}{l}\text { Services } \\
\text { (6) }\end{array}$ \\
\hline \multirow[t]{2}{*}{$C F_{i t}$} & $0.154^{\star \star \star}(0.018)$ & $0.096^{\star \star \star}(0.020)$ & $0.227^{\star \star \star}(0.032)$ & $0.160^{* \star \star}(0.018)$ & $0.108^{\star \star \star}(0.020)$ & $0.228^{\star \star \star}(0.032)$ \\
\hline & {$[0.119 ; 0.189]$} & {$[0.056 ; 0.135]$} & {$[0.165 ; 0.290]$} & {$[0.124 ; 0.195]$} & {$[0.068 ; 0.148]$} & {$[0.166 ; 0.291]$} \\
\hline \multirow[t]{2}{*}{$\Delta y_{i t}$} & $0.013 * * *(0.003)$ & $0.016 * * *(0.004)$ & $0.011 * * \quad(0.004)$ & $0.015 * * *(0.003)$ & $0.018 * * *(0.004)$ & $0.011 * * \quad(0.005)$ \\
\hline & {$[0.007 ; 0.019]$} & {$[0.007 ; 0.024]$} & {$[0.002 ; 0.019]$} & {$[0.008 ; 0.021]$} & {$[0.009 ; 0.026]$} & {$[0.002 ; 0.020]$} \\
\hline \multirow[t]{2}{*}{$S_{i t}$} & $0.018^{\star \star \star}(0.004)$ & $0.022^{* * *}(0.005)$ & $0.015^{\star *} \quad(0.006)$ & $0.016^{\star \star *}(0.004)$ & $0.019^{\star * \star}(0.005)$ & $0.016^{\star \star} \quad(0.007)$ \\
\hline & {$[0.010 ; 0.026]$} & {$[0.012 ; 0.032]$} & {$[0.003 ; 0.027]$} & {$[0.008 ; 0.025]$} & {$[0.009 ; 0.030]$} & {$[0.003 ; 0.029]$} \\
\hline \multirow[t]{2}{*}{$I_{i t}$} & $-0.205^{\star \star \star}(0.012)$ & $-0.150^{\star * \star}(0.014)$ & $-0.269^{* \star *}(0.020)$ & $-0.202^{* \star *}(0.012)$ & $-0.142^{\star \star \star}(0.014)$ & $-0.270^{\star \star *}(0.020)$ \\
\hline & {$[-0.228 ;-0.181]$} & {$[-0.177 ;-0.123]$} & [-0.308;-0.230] & {$[-0.225 ;-0.178]$} & {$[-0.170 ;-0.115]$} & {$[-0.309 ;-0.230]$} \\
\hline \multirow[t]{2}{*}{$\Delta N W C_{i t}$} & $-0.124 * * *(0.006)$ & $-0.109^{* * *}(0.008)$ & $-0.140^{* * * *}(0.009)$ & $-0.124 * * *(0.006)$ & $-0.109^{* * *}(0.008)$ & $-0.139 * * *(0.009)$ \\
\hline & {$[-0.136 ;-0.112]$} & {$[-0.124 ;-0.094]$} & {$[-0.159 ;-0.122]$} & {$[-0.135 ;-0.112]$} & {$[-0.124 ;-0.094]$} & {$[-0.157 ;-0.121]$} \\
\hline \multirow[t]{2}{*}{$I S S_{i t}$} & $0.076^{\star * *}(0.006)$ & $0.059^{\star \star \star}(0.008)$ & $0.095^{\star \star \star}(0.010)$ & $0.078^{\star \star \star}(0.006)$ & $0.063^{\star \star \star}(0.008)$ & $0.095^{\star \star \star}(0.010)$ \\
\hline & {$[0.064 ; 0.089]$} & {$[0.044 ; 0.074]$} & {$[0.076 ; 0.114]$} & {$[0.066 ; 0.091]$} & {$[0.048 ; 0.078]$} & {$[0.075 ; 0.114]$} \\
\hline \multirow[t]{2}{*}{$\Delta I N T_{i t}$} & $-0.260 * * *(0.097)$ & $-0.215^{*} \quad(0.120)$ & $-0.331 * * \quad(0.155)$ & $-0.126 \quad(0.104)$ & $-0.057 \quad(0.130)$ & $-0.215 \quad(0.166)$ \\
\hline & {$[-0.450 ;-0.071]$} & {$[-0.450 ; 0.021]$} & {$[-0.635 ;-0.026]$} & {$[-0.329 ; 0.077]$} & {$[-0.311 ; 0.197]$} & {$[-0.540 ; 0.110]$} \\
\hline \multirow[t]{2}{*}{ Finl $_{\text {it }}$} & $-0.123^{\star \star \star}(0.019)$ & $-0.088^{\star \star \star}(0.025)$ & $-0.157^{\star \star \star}(0.028)$ & $-0.126^{\star \star \star}(0.018)$ & $-0.091^{\star \star \star}(0.024)$ & $-0.161^{\star \star \star}(0.027)$ \\
\hline & {$[-0.159 ;-0.086]$} & {$[-0.136 ;-0.039]$} & {$[-0.211 ;-0.103]$} & {$[-0.162 ;-0.090]$} & {$[-0.139 ;-0.044]$} & {$[-0.215 ;-0.107]$} \\
\hline \multicolumn{7}{|l|}{ Dummies } \\
\hline Year & NO & NO & NO & YES & YES & YES \\
\hline Industry & NO & NO & NO & YES & YES & YES \\
\hline Observations & 13,874 & 7,590 & 6,256 & 13,874 & 7,590 & 6,256 \\
\hline No. of firms & 4,322 & 2,277 & 2,043 & 4,322 & 2,277 & 2,043 \\
\hline Hansen p-val. & 0.368 & 0.206 & 0.819 & 0.560 & 0.455 & 0.830 \\
\hline R-squared & 0.155 & 0.125 & 0.193 & 0.159 & 0.132 & 0.195 \\
\hline
\end{tabular}

Notes: Regression of model (2). Robust standard errors in parentheses; $95 \%$ confidence intervals in brackets. ${ }^{\star \star *}$, ${ }^{* *}$, and ${ }^{*}$ denote statistical significance at the $.01, .05$, and .10 levels, respectively. Further test statistics available from the authors. 


\section{Table A2. CCFS estimation with different proxies for investment opportunities}

\begin{tabular}{|c|c|c|c|c|c|c|c|c|c|}
\hline \multirow[t]{3}{*}{ VARIABLES } & \multicolumn{3}{|c|}{ Forward investment } & \multicolumn{3}{|l|}{ Lead investment } & \multicolumn{3}{|c|}{ Forward sales growth } \\
\hline & Overall & Manufacturing & Services & Overall & Manufacturing & Services & Overall & Manufacturing & Services \\
\hline & (1) & (2) & (3) & (4) & (5) & (6) & (7) & (8) & (9) \\
\hline \multirow[t]{2}{*}{$C F_{i t}$} & $0.141^{\star \star \star}$ & $0.096^{\star \star \star}$ & $0.204^{\star \star \star}$ & $0.122^{\star \star \star}$ & $0.097^{\star \star \star \star}$ & $0.168^{\star \star \star}$ & $0.137^{\star \star \star *}$ & $0.107^{\star \star \star}$ & $0.173^{\star \star \star \star}$ \\
\hline & {$[0.099 ; 0.184]$} & {$[0.051 ; 0.141]$} & {$[0.125 ; 0.282]$} & {$[0.070 ; 0.175]$} & {$[0.037 ; 0.157]$} & {$[0.083 ; 0.253]$} & {$[0.103 ; 0.172]$} & {$[0.069 ; 0.145]$} & {$[0.111 ; 0.234]$} \\
\hline \multirow[t]{2}{*}{$I_{i(t+1)}$} & 0.014 & 0.021 & 0.014 & & & & & & \\
\hline & {$[-0.014 ; 0.041]$} & {$[-0.010 ; 0.052]$} & {$[-0.035 ; 0.062]$} & & & & & & \\
\hline \multirow[t]{2}{*}{$\left(I_{i(t+1)}+I_{i(t+2)}\right) / I_{i t}$} & & & & $0.000^{\star \star}$ & 0.000 & $0.000^{* \star}$ & & & \\
\hline & & & & {$[0.000 ; 0.000]$} & {$[-0.000 ; 0.000]$} & {$[0.000 ; 0.000]$} & & & \\
\hline \multirow[t]{2}{*}{$\Delta y_{i(t+1)}$} & & & & & & & $-0.012^{\star \star \star *}$ & $-0.011^{\star \star}$ & $-0.012^{\star \star}$ \\
\hline & & & & & & & {$[-0.018 ;-0.006]$} & {$[-0.020 ;-0.003]$} & {$[-0.020 ;-0.003]$} \\
\hline \multirow[t]{2}{*}{$\Delta y_{i t}$} & $0.017^{\star \star \star}$ & $0.020^{\star \star \star}$ & $0.014^{\star \star}$ & $0.020^{\star \star \star}$ & $0.014^{*}$ & $0.030^{\star \star \star}$ & $0.011^{\star \star \star}$ & $0.016^{\star \star \star}$ & 0.006 \\
\hline & {$[0.010 ; 0.025]$} & {$[0.011 ; 0.030]$} & {$[0.002 ; 0.026]$} & {$[0.009 ; 0.031]$} & {$[0.002 ; 0.025]$} & {$[0.013 ; 0.047]$} & {$[0.005 ; 0.017]$} & {$[0.008 ; 0.024]$} & {$[-0.003 ; 0.015]$} \\
\hline \multirow[t]{2}{*}{$s_{i t}$} & $0.022^{\star \star \star}$ & $0.024^{\star \star \star}$ & $0.025^{\star \star}$ & 0.007 & 0.015 & 0.004 & $0.016^{\star \star \star *}$ & $0.020^{\star \star *}$ & $0.014^{\star}$ \\
\hline & {$[0.011 ; 0.033]$} & {$[0.012 ; 0.037]$} & {$[0.007 ; 0.042]$} & {$[-0.008 ; 0.022]$} & {$[-0.003 ; 0.033]$} & {$[-0.020 ; 0.028]$} & {$[0.007 ; 0.025]$} & {$[0.009 ; 0.031]$} & {$[0.000 ; 0.027]$} \\
\hline \multirow[t]{2}{*}{$l_{i t}$} & $-0.222^{\star * *}$ & $-0.171^{\star \star \star}$ & $-0.279^{\star \star \star}$ & $-0.265^{\star \star \star}$ & $-0.221^{\star \star \star}$ & $-0.331^{\star \star \star}$ & $-0.210^{\star \star \star}$ & $-0.165^{\star \star \star}$ & $-0.260^{\star \star \star *}$ \\
\hline & {$[-0.250 ;-0.194]$} & {$[-0.203 ;-0.139]$} & {$[-0.326 ;-0.233]$} & {$[-0.304 ;-0.225]$} & {$[-0.267 ;-0.176]$} & {$[-0.400 ;-0.263]$} & {$[-0.233 ;-0.186]$} & {$[-0.193 ;-0.138]$} & {$[-0.298 ;-0.222]$} \\
\hline \multirow[t]{2}{*}{$\Delta N W c_{i t}$} & $-0.132^{\star * *}$ & $-0.116^{\star \star \star}$ & $-0.149^{\star \star \star}$ & $-0.143^{\star \star \star}$ & $-0.115^{\star \star \star}$ & $-0.185^{\star \star \star}$ & $-0.125^{\star \star \star}$ & $-0.111^{\star \star \star}$ & $-0.137^{\star \star \star \star}$ \\
\hline & {$[-0.145 ;-0.118]$} & {$[-0.133 ;-0.100]$} & {$[-0.171 ;-0.127]$} & {$[-0.163 ;-0.123]$} & {$[-0.137 ;-0.093]$} & {$[-0.218 ;-0.151]$} & {$[-0.137 ;-0.114]$} & {$[-0.126 ;-0.097]$} & {$[-0.154 ;-0.120]$} \\
\hline \multirow[t]{2}{*}{$I S s_{i t}$} & $0.085^{\star \star \star}$ & $0.075^{\star \star \star}$ & $0.093^{\star \star \star}$ & $0.101^{\star \star \star}$ & $0.093^{\star \star \star}$ & $0.108^{\star \star \star}$ & $0.080^{\star \star \star}$ & $0.071^{\star \star \star}$ & $0.088^{\star \star \star}$ \\
\hline & {$[0.070 ; 0.099]$} & {$[0.057 ; 0.092]$} & {$[0.071 ; 0.115]$} & {$[0.079 ; 0.122]$} & {$[0.066 ; 0.119]$} & {$[0.074 ; 0.141]$} & {$[0.068 ; 0.092]$} & {$[0.056 ; 0.087]$} & {$[0.069 ; 0.107]$} \\
\hline \multirow[t]{2}{*}{$\Delta I N T_{i t}$} & 0.096 & -0.163 & 0.323 & 0.124 & 0.119 & 0.099 & 0.048 & -0.006 & 0.074 \\
\hline & {$[-0.148 ; 0.339]$} & {$[-0.466 ; 0.141]$} & {$[-0.064 ; 0.710]$} & {$[-0.216 ; 0.465]$} & {$[-0.328 ; 0.567]$} & {$[-0.411 ; 0.608]$} & {$[-0.147 ; 0.244]$} & {$[-0.260 ; 0.247]$} & {$[-0.224 ; 0.373]$} \\
\hline \multirow[t]{2}{*}{ Finl $_{i t}$} & $-0.118^{\star \star \star}$ & $-0.090^{\star \star \star}$ & $-0.144^{\star \star \star}$ & $-0.129^{\star \star \star}$ & $-0.091^{*}$ & $-0.158^{+\star \star \star *}$ & $-0.115^{\star \star \star \star}$ & $-0.073^{\text {t*t}}$ & $-0.158^{\text {t**t}}$ \\
\hline & {$[-0.160 ;-0.076]$} & {$[-0.144 ;-0.036]$} & {$[-0.209 ;-0.080]$} & {$[-0.190 ;-0.068]$} & {$[-0.170 ;-0.013]$} & {$[-0.249 ;-0.067]$} & {$[-0.149 ;-0.080]$} & {$[-0.118 ;-0.028]$} & {$[-0.210 ;-0.105]$} \\
\hline \multicolumn{10}{|l|}{ Dummies: } \\
\hline Year & YES & YES & YES & YES & YES & YES & YES & YES & YES \\
\hline Industry & YES & YES & YES & YES & YES & YES & YES & YES & YES \\
\hline Observations & 13,874 & 7,590 & 6,256 & 13,874 & 7,590 & 6,256 & 13,874 & 7,590 & 6,256 \\
\hline No. of firms & 4,322 & 2,277 & 2,043 & 4,322 & 2,277 & 2,043 & 4,322 & 2,277 & 2,043 \\
\hline Hansen p-val. & 0.368 & 0.206 & 0.819 & 0.463 & 0.430 & 0.751 & 0.560 & 0.455 & 0.830 \\
\hline R-squared & 0.155 & 0.125 & 0.193 & 0.158 & 0.131 & 0.195 & 0.159 & 0.132 & 0.195 \\
\hline
\end{tabular}

Notes: Regression of model (2) with forward investment $\left(I_{i(t+1)}\right)$, sales growth $\left(\Delta y_{i(t+1)}\right)$ and lead investment $\left(I_{i(t+2)}+I_{i(t+1)}\right) / I_{i t}$ as alternative proxies for investment opportunities. We report $90 \%$ confidence intervals in brackets. $* * *$, **, and $*$ denote statistical significance at the .01 , .05 , and .10 levels, respectively. Further test statistics available from the authors on request. 


\section{Table A3. Validation of HOV index}

\begin{tabular}{|c|c|c|c|c|}
\hline \multirow[t]{2}{*}{ VARIABLES } & \multicolumn{4}{|l|}{ HOV index quartiles } \\
\hline & Q1 & Q2 & Q3 & Q4 \\
\hline$C F_{i t}$ & $-0.2113 * * *(0.041)$ & $-0.0499 * * *(0.019)$ & $0.1467 * * *(0.022)$ & $0.4843^{* * *}(0.037)$ \\
\hline$\Delta y_{i t}$ & $0.0077 \quad(0.007)$ & $0.0050 \quad(0.004)$ & $0.0032 \quad(0.004)$ & $0.0259 * * *(0.007)$ \\
\hline$I_{i t}$ & $-0.2563 * * *(0.030)$ & $-0.0742 * * *(0.014)$ & $-0.1491 * * *(0.018)$ & $-0.2730^{* * *}(0.029)$ \\
\hline$\Delta N W C_{i t}$ & $-0.1250^{* * *}(0.014)$ & $-0.0552 * * *(0.007)$ & $-0.0859 * * *(0.009)$ & $-0.1992 * * *(0.015)$ \\
\hline$I S S_{i t}$ & $0.1297 * * *(0.014)$ & $0.0377 * * *(0.007)$ & $0.0478^{* * *}(0.009)$ & $0.0963^{* * *}(0.016)$ \\
\hline$\Delta I N T_{i t}$ & $-0.0349 \quad(0.257)$ & $\begin{array}{ll}-0.1315 \quad(0.109) \\
\end{array}$ & $-0.2509^{* *}(0.112)$ & $-0.4780^{*} \quad(0.244)$ \\
\hline FinI $_{i t}$ & $-0.2613^{* * *}(0.058)$ & $-0.0331^{* *}(0.014)$ & $-0.0715^{\star \star \star}(0.025)$ & $-0.1465^{\star \star \star}(0.054)$ \\
\hline Observations & 2,633 & 4,443 & 4,184 & 2,614 \\
\hline Number of firms & 893 & 1,274 & 1,255 & 900 \\
\hline Hansen chi2 p-value & 0.063 & 0.174 & 0.009 & 0.135 \\
\hline R-squared & 0.261 & 0.064 & 0.105 & 0.310 \\
\hline
\end{tabular}

Notes: Regression of model (2) by quartiles of the HOV index. We should note that using interactions, as in model (4), would result in collinearity problems, by construction of the index. Robust standard errors in parentheses. ${ }^{\star \star *}$, ${ }^{\star *}$, and * denote statistical significance at the $.01, .05$, and .10 levels, respectively. Further test statistics available from the authors on request. 